\title{
Kutanöz immüntolerans ve otoimmünite
}

\section{Cutaneous immune tolerance and autoimmunity}

Sibel Doğan*, Nilgün Atakan**

*Ankara Numune Eğitim ve Araștırma Hastanesi, Deri ve Zührevi Hastalıkları Kliniği, Ankara, Türkiye

**Hacettepe Üniversitesi Tıp Fakültesi, Deri ve Zührevi Hastalıkları Anabilim Dalı, Ankara, Türkiye

\section{Özet}

Deri vücudun en önemli savunma bariyeri olarak hücresel aracilı ve humoral immün reaksiyonların hedefi olabilen bir organdır. Immüntolerans organizmanın kendine ait olan antijenlerine yanıtsız kalması, bu antijenlere karşı herhangi bir immün yanıt oluşturmaması olarak tanımlanmaktadır. Immüntoleransın bozulduğu ve organizmanın kendi antijenlerine karşı yanıt oluşturduğu durumlarda otoimmünite gelişmektedir. Kutanöz otoimmünite otoantikorlar ve otoreaktif T hücrelerin varlı̆̆ı ile karakterizedir. Konağın kendisine karşı immüntoleransının kaybını engellemek için çeşitli mekanizmalar gelişmiştir. Bu derlemede kutanöz otoimmün hastalıkların gelişiminde ve kutanöz toleransta önemli rol oynadığı düşünülen yeni immünolojik öğeler ve mekanizmalardan ve en sık görülen kutanöz otoimmün hastalıklardan bahsedilecektir. (Türkderm 2013; 47: Özel Sayı 1: 41-5)

Anahtar Kelime: Otoimmünite, immüntolerans, otoantikor, otoimmün deri hastalığı

\section{Summary}

As the most important defense barier of the body, skin is an organ which can be a target for both cellular and humoral immune reactions. Immune tolerance is defined as the unresponsiveness of organism to antigens belonging to itself, immuntolerant organism does not show an immunologic reaction to its self antigens. When immune tolerance is corrupted, organism begins to show immunologic response to autolog antigens generating autoimmunity. Cutaneous autoimmunity is characterized by the presence of autoantibodies and autoreactive $T$ cells. There are mechanisms to avoid the loss of immune tolerance of the host to itself. In this review, new immunologic elements and mechanisms proposed to participate in the development of cutaneous autoimmune diseases and cutaneous tolerance are discussed along with common autoimmune skin diseases. (Turkderm 2013; 47: Suppl 1: 41-5)

Key Words: Autoimmunity, immune tolerance, autoantibody, autoimmune skin disease

\section{Giriş}

Kutanöz immüntolerans ve otoimmünite

Vücudun en büyük organı olarak deri dış ortamla konak arasında en önemli bariyeri oluşturmaktadır. Derimiz konağın bütünlüğünü koruma işlevini sağlar iken aynı zamanda dış dünya ile iletişimde olmasını da sağlamak zorundadır. ${ }^{1}$ Dış ortamda bulunan çevresel ajanlar ve zararlı patojenler ilk olarak deri ile temasa geçerler. Deri bariyeri kimyasal, hücresel ve moleküler olarak çeşitli bileşenlerden oluşan çift taraflı selektif bir yapı göstermesi gereken kompleks bir sistemdir, organizmanın devamı için işlevlerinin en önemlisi olan savunma fonksiyonunu bünyesinde bulundurduğu immünolojik sistem elemanları ile yerine getirmektedir 1 ,2. Immunolojik sistemin tehlike anında savunma reaksiyonu oluşturması ve zararlı organizmaların yok edilerek vücuda girişinin engellenmesini sağlaması beklenir, aynı şiddetli reaksiyonun zararsız maddelere ve konağa ait olan antijenlere karşı oluşması ise organizmanın zararınadır. Bu nedenle eldeki bu çok önemli savunma mekanizmasının kontrol altında tutulması ve organizmanın kendine yönelen bir silah haline gelmemesi oldukça önemlidir. Deride immün yanıtın kontrolünün kaybedildiği ve organizmanın kendisine ait antijenlerine karşı yönelen bir immün sistem yanıtı bozukluğu geliştiğinde derinin otoimmün hastalıkları başığı altında incelenen çok çeşitli bir hastalık grubu ile karşılaşılmaktadır1-6. 
Deri hücresel aracılı ve humoral immün reaksiyonların hedefi olabilen bir organdır. SALT (skin-associated lymphoid tissues) terimi ile de derinin bölgesel olarak kendine özgü ve zengin immünolojik bileşenlere sahip bir lenfoid doku olarak algılanması sağlanmaya çalışılmaktadır1,5. Buna göre SALT, deri yerleşimli dendritik antijen sunucu hücre $(A P C)$, keratinositler, drenajı sağlayan lenf nodları ve sensitize olmuş T lenfositlerden oluşur ${ }^{5}$. Deride gelişen immün yanıtlar hem doğal ve hem de adaptif (akkiz) immün sistem elemanları tarafından oluşturulmaktadır. Kısaca immün yanıın iki ana bileşeni olan doğal ve akkiz immün yanıtın özelliklerine bakacak olursak, doğal immün yanıt reaksiyonlarının tipik olarak hızlı, ayırt edici özelliği zayıf ve hafıza göstermeyen tipte reaksiyonlar olduğunu görmekteyiz. Tersine akkiz immün sistem reaksiyonları ise çok yüksek derecede spesifite gösterirler, hafıza özellikleri bulunur ancak oluşmaları için belli bir süre gerekir7,8. Sonuç olarak doğal ve akkiz immün yanıt birbirini izleyen ardışık iki süreç olarak kabul edilir 1,2,7,8. Her iki sistemin de kutanöz otoimmün hastalıkların gelişiminde ve kütanöz toleransta önemli rol oynadığı düşünülse de bu derlemede daha çok kanıtlanmış ve üzerinde çalışılmaya devam edilen somut bilgiler ışığında kutanöz immüntolerans ve otoimmünitedeki yeni bilgilerden bahsedilecektir1,8.

\section{Kutanöz immüntolerans}

İmmüntolerans veya kendine karşı tolerans (self-tolerance) organizmanın kendine ait olan antijenlerine yanıtsı kalması, bu antijenlere karşı herhangi bir immün yanıt oluşturmaması olarak tanımlanmaktadır7,8. Immüntoleransın bozulduğu ve organizmanın otolog antijenlerine karşı yanıt oluşturduğu durumlarda otoimmünite gelişmektedir2,7-9. Kutanöz otoimmünite otoantikorlar ve otoreaktif $T$ hücrelerin varlığı ile karakterizedir. Konağın kendisine karşı immuntoleransının kaybını engellemek için çeşitli mekanizmalar gelişmiştir. İmmüntolerans mekanizmalarına örnek olarak aktivasyon ile indüklenen hücre ölümü, delesyon, yanıtsız kalma (ignorance) ve otoreaktivitenin aktif supresyonu olarak tanımlanmış çeşitli immünolojik yanıtlar gösterilebilir1,2,8-10.

Santral immüntolerans fetal hayatla başlar ve postnatal olarak periferal tolerans gelişmeye devam eder. Santral tolerans primer lenfoid organlar olan timus ve kemik iliğinde başlar2,8. Burada immatür ancak organizmaya karşı reaktif olduğu saptanan lenfositler apopitoz ile yok edilir. Bu mekanizmaya delesyon adı verilmektedir2,8-10. Santral toleransın immuntoleransa uygun olmayan lenfosit popülasyonunu elimine etmede ana rolü oynadığı düşünülmektedir. Matür lenfosit repertuarında yer alması uygun olmayan, kendi MHC (major histokompatibilite) antijenlerine TCR ( $T$ hücre reseptörü) aracılığı ile reaksiyon gösteren lenfosit popülasyonu negatif seleksiyon ile yok edilir2,8,9. T hücreleri için santral tolerans timusta gelişirken, B hücreleri için santral toleransın geliştiği lenfoid organ kemik iliğidir. Burada otoreaktif B lenfositler negatif seleksiyon ile apopitoza uğratılarak yok edilirler8,10. Yine de otoreaktif olan ve yok edilemeyen lenfositlerin primer lenfoid organlardan dolanıma çıkmaları söz konusudur. Bu durumda ise periferal immüntolerans mekanizmaları çalıştırılır. Periferik dolanıma çıkmayı başarabilen matür otoreaktif lenfositler inaktive edilirler. Bu yolla inaktivasyona anerji de denilmektedir. Periferal tolerans ayrıca otoreaktif hücrelerin öldürülerek yok edilmesi yani delesyonu ve suprese edilmesi ile de sağlanabilmektedir2,8-10.

Kutanöz otoimmünitede $\mathrm{T}$ hücrelerin rolü

Otoimmün hastalıklardan elde edilen deneysel veriler ışı̆̆ında organ spesifik otoimmün hastalıkların IFN- $\gamma$ (interferon gama) üreten CD4+ yardımcı Th1 (T hücre 1) fenotipindeki hücreler ile oluştuğu bilinmektedir11. Alerjik ensefalomyelit, otoimmün diabetes mellitus, otoimmün artrit, deneysel kolit ve kutanöz gecikmiş tip hipersensitivite reaksiyonu deneysel ortamda bu hücrelerin kullanılarak hastalık oluştuğunun gösterildiği önemli immünolojik klinik antiteler olarak literatürde yer almaktadır11-16. Benzer olarak baskın Th1 sitokin profili psoriazisde de görülmektedir1,2,11,17. Psoriazis immünpatogenezinde Th1 profile ek olarak interlökin-17 (IL17) üretimi ile benzer etkiler oluşturduğu gözlenen farklı bir lenfosit subgrubu olan Th17 hücrelerin rol oynadığı gösterilmiştir11,18. In vivo ortamda, Th1 hücrelerin indüksiyonu IL-12 bağımlı iken, Th17 hücrelerin indüksiyonu için gerekli sitokinler IL-6 ve IL-23 olarak tanımlanmıştır ${ }^{11,18,19 .}$ IL-6, IL-12 ve IL23 'ün deneysel ortamda farelerde organ spesifik otoimmün hastalıkların gelişiminde önemli rol oynadıkları kanıtlanmıştır ${ }^{11,19}$. Psoriazisin diğer önemli otoimmün hastalıklardan multipl skleroz, otoimmün diabetes mellitus ve inflamatuvar barsak hastalıkları ile ortak yönleri ve sık birliktelik göstermesi göz önüne alındığında, oligoklonal olarak benzer yapıdaki sitokin profili ile indüklenen lenfositlerin hedef organlarda infiltrasyonu ile otoimmün etyopatogenezin geliştiği desteklenmiş olmaktadır11,20. Psoriazis son yıllarda Th1/Th17 ile indüklenen inflamatuvar otoimmün bir hastalık olarak kabul edilmektedir. IL12/ IL-23 blokajı sağlayan monoklonal antikorlar ile etyopatogenezde aydınlanan bu yolağın blokajının tedavide yüz güldürücü sonuçlar verdiği gözlemlenmektedir11,18-20. Th1/Th17 yanıtının baskılanması için gündemdeki bir diğer yöntem ise bu yanıtın Th2 sitokin profiline kaydırıması yönündedir. Bunun için kullanılan IL-4 ile faz I/II çalışması yürütülen ciddi psoriazisli hastalarda da 6 hafta sonunda psoriazis de belirgin iyileşme elde edildiğine dair veriler elde edilmiştir21. IL-4 kullanımı sonrasında psoriatik plaklar içerisinde dermiste predomine olan CCR5 eksprese eden Th1 hücrelerin yerine CCR-5 negatif T hücrelerin geldiği gösterilebilmiştir11,21-23.

Kutanöz otoimmünitede bir diğer önemli hücre grubu regülatör (supresör) $T$ hücrelerdir10,11. Regülatör $T$ hücreleri, efektör $T$ hücrelerin aktivasyonu ve fonksiyonunun inhibisyonunda kilit rol oynarlar. T regülatör hücrelerin bir alt grubu olarak tanımlanan CD4+ CD25+ $T$ hücrelerin farelerde organ spesifik otoimmünite oluşumunun supresyonunda rol oynadığı gösterilmiştir10,24. İnsan regülatör T hücreleri ile ilgili son görüş, inflamatuvar ve otoimmün büllöz hastalıkların patogenezinde bu hücrelerin rol oynadığı yönündedir. T regülatör hücrelerin modülasyonuna yönelik yapılacak girişimlerin yeni tedavi modaliteleri açısından umut verici olabileceği düşünülmektedir8,10,24. Tip 1 diabetes mellituslu hastaların hastalık başlangııında humanize anti-CD3 antikor tedavisi ile hastalık progresyonu engellenebilmiştir25. Bu tedavi ile otoreaktif T hücrelerinin aktivasyon ile indüklenen hücre ölümünün sağlanmasının yanı sıra antiCD3 antikor enjeksiyonları ile regülatör T hücrelerin aktivasyonunun sağlandığı ve böylece regülatör $T$ hücrelerinin de faydalı tedavi edici etkinlik oluşturdukları düşünülmektedir10,25.

Regülatör T hücre popülasyonunun azaldığı gösterilmiş olan önemli bir hastalık ise psoriazisdir. Psoriazisli hastalarda periferik regülatör T hücre sayısı azalmıştır ve psoriatik lezyonlarda azalmış supresör hücre fonksiyonu olduğu gösterilmiştir 10,26. Bu nedenle psoriazisli hastaların da anti-CD3 antikor tedavisinden fayda görebileceği düşünülmektedir. PV (pemfigus vulgaris) keratinosit aderansını sağlayan dezmozomal 
protein Dsg-3'e (desmoglein-3) karşı otoantikor oluşumu ile karakterize nadir bir otoimmmün deri hastalığıdır1,6,10,27. Her ne kadar patogenezden sorumlu ana mekanizmanın otoantikorlar ve bunları oluşturan B lenfositler olduğu bilinse de, Dsg-3 otoreaktif T hücre klonları pemfiguslu hastalarda tanımlanmıştır10,27,28. Pemfiguslu hastalarda T hücrelerin, B hücrelere otoantikor oluşturan plazma hücrelerine dönüşmede yardımcı oldukları düşünülmektedir27,28. Dsg-3'e spesifik olan tip 1 regülatör $T$ hücrelerin ise pemfiguslu hastalarda az sayıda bulundukları gösterilmiştir. Bu hücrelerin supresör fonksiyonlarının da pemfiguslu hastalarda sağlıklı kontrol grubundaki bireylere göre azalmış olduğu saptanmıştır10,26-28. Bu nedenle ileride regülatör T hücrelerin aktivasyon ve ekspansiyonunu sağlayan tedaviler ile insanlarda organ spesifik otoimmün hastalıklara örnek teşkil eden diabetes mellitus ve pemfigus gibi hastalıklarda ilerleme kaydedilebileceği düşünülmektedir10,28.

Otoimmün hastalıkların engellenmesinde son dönemlerde tartışılan yeni bir yolak ise $T$ hücre kostimülatör sinyal blokajıdır29. Bilindiği gibi naif $T$ hücreleri ilk proliferatif sikluslarını başlatabilmek ve antijen spesifik yanıt oluşturabilmek için TCR aracılığı ile MHC moleküllerini tanımaya intiyaç duyarlar, T hücrelerin G1 hücre fazına girerek hücre siklusunun progresyonu ve IL-2 ekspresyonu yapabilmesi için ise ikinci bir sinyale ihtiyaç duyulmaktadır29,30. Bu ikinci sinyal, ortamdaki IL-2 gibi çözünür maddelere ve bazı hücre yüzey moleküllerinin TCR aracılı antijen prezentasyonunun tamamlayıcı özellikte ve elzem olan diğer kostimülatör sinyalleri oluşturmasına bağlıdır29,31,32. En iyi bilinen ikincil sinyalden sorumlu kostimulatör yolaklar arasında antijen sunucu hücre ve T lenfosit üzerinde karşııklı etkileşim gösteren hücre yüzey moleküllerinin tanımlanması ile ortaya konan B7-CD28/CTLA-4 ve CD40-CD40L molekül etkileşimleri bulunmaktadır31,32. Yapılan hayvan çalısmalarında SLE (sistemik lupus eritematozus) geliştirmiş olan farelerde CTLA-4-Ig enjeksiyonları ile tedavinin ertelendiği durumlarda dahi anti-DNA antikorların oluşumunun blokajı sağlanabilmiştir29,33. CD40-CD40L sinyal etkileşiminin blokajı ile farelerde Th1 ile tanınan haptene karşı uzun süreli yanıtsızlık elde edilerek, gelişen alerjik kontakt dermatit tablosunun engellenebileceği gösterilmiştir29,34.

\section{Kutanöz otoimmünitede otoantikorların rolü}

PV antikor ile ilişkili otoimmün deri hastalıklarının prototipidir1,6,27. Dezmozomal adezyon molekülü Dsg-3'e karşı gelişen otoantikor nedeni ile keratinosit adezyonun bozulması hastalık patogenezindeki en önemli immün basamak olarak tanımlanmaktadır27,35. PV'de otoantikor oluşumu poliklonaldir ve aktif hastalığı olan PV'li hastalarda daha çok bulunan Ig alt grubu IgG4'tür27,35. Pemfiguslu hastaların serumlarında pemfigus foliaseus'ta görülen Dsg-1'e karşı olduğu gibi, dezmokolin ve diğer transmembranöz dezmozom komponentlerine karşı da otoantikorlar saptanabilmektedir27,35. Interselüler antikorların patojenik özellik göstererek hastalık gelişimi ve şiddetinden sorumlu olduğunu kanıtlayan net immünolojik veriler günümüzde literatürde açık bir şekilde yer almaktadır27,35-38. Deneysel çalışmalarda antikorların in vitro olarak normal insan derisi kültürlerinde kompleman yokluğunda dahi akantolize neden olduğu gösterilmiştir27,39. İn vivo ortamda yenidoğan farelerin peritonuna interselüler antikor injeksiyonu sonrasında insanda gelişen pemfigusa klinik, histolojik ve immunolojik yönlerden oldukça benzer olan bir tablo geliştiği kanıtlanmıştır36. Kliniktede transplasental olarak yenidoğana geçmiş olan interselüler antikorlar nedeni ile doğum sonrası antikorlar yıkılana kadara geçen bir süre devam eden geçici neonatal pemfigus tablosu aktif pemfiguslu annelerin yenidoğan bebeklerinde tanımlanmış olan bir antitedir27,37 Yine tedavi amaçlı kullanılan plazmaferez gibi yöntemler ile de dolanımda fazla miktardaki interselüler antikorların temizlenmesi ile pemfiguslu hastalarda kısmi klinik remisyonlar elde edilebilmektedir27,38. Interselüler antikorlar keratinosit membranına bağlanarak apopitotik mekanizmaları tetiklerler ve bazal hücrelerde apopitoza neden olurlar. Bunu takip eden basamaklarda ekstradezmozomal desmogleinler internalize olur ve tam bir hücreler arası ayrılmayla pemfigus vulgaris için klasik görünüm olan ilerlemiş akantoliz gelişir. Bu mekanizmada apopitotik enzimlerin akantoliz ile sonuçlanan süreçteki etkinliğini vurgulamak için apopitoliz terimi de kullanılabilmektedir27,40.

\section{Kutanöz otoimmünite ile ilişkili diğer hastalıklar}

Kutanöz otoimmünite ile ilişkili bir diğer önemli ve kronik deri hastalığı vitiligodur. Vitiligo kompleks bir patogeneze sahiptir. Etyolojide melanositlerin otoimmün mekanizmalar ile yok edilmesinin yanı sıra melanositlere ait intrinsik defektler, antioksidan sistemlere ait yetersizlikler nedeni ile melanositlerin progresif kaybı, melanositlerin hayatta kalma kapasitelerinde azalma, transepidermal melanositoraji olarak tanımlanan melanositlerin transepidermal kaybı ve diğer nöral hipotezlerin desteklenmesi vitiligonun multifaktöryel poligenik bir hastalık olduğunu göstermektedir41-45. Yine de vitiligo için kuvvetli bir etyopatogenetik mekanizma olarak otoimmüniteye dair kuvvetli kanıtlar bulunmaktadı41-43. Tiroid hastalıkları özellikle Hashimoto tiroiditi ve Graves Hastalığı, diabetes mellitus, Addison hastalığı gibi endokrinopatiler, pernisiyöz anemi, psoriazis klinikte sıklıkla vitiligoya eşlik eden diğer otoimmün hastalıklar arasında sayılmaktadır 41,43 Vitiligoda melanosit hasarından hücresel ve humoral immünitenin her ikisinin birlikte sorumlu olduğu düşünülmektedir. Melanositlere direkt sitotoksik etki göstererek zarar veren otoreaktif CD8+ T hücrelerin aktive olarak vitiligolu hastalarda perilezyonal olarak yerleştiği gösterilmiştir44. Vitiligolu hastaların serumlarında tirozinaz, TYRP1 ve TYRP2 (tirozinaz ilişkili protein) gibi melanositlere ait olan antijenlere karşı otoantikorların varlığı gösterilmiştir41-43. Deneysel bir çalışma modelinde ise vitiligolu hastaların dolanımında bulunan otoantikorların farelere enjeksiyonu ile de sağlıklı deride vitiligo geliştiği gösterilebilmiştir41,43.

AA (alopesi areata) göreceli olarak dermatoloji pratiğinde sık olarak karşılaşabildiğimiz otoimmün bir başka deri hastalığıdır. Folliküler antijenlere karşı T hücrelerin oluşturduğu yanıt sonrası klinikte yamalar halinde saç dökülmesi ile karşımıza çıkan AA konusunda yapılan birçok araştırma ile $T$ hücrelerinin hastalık patogenezinde önemli rol oynadığını desteklenmiştir46-51. Kıl follikülüne ait komponentleri de içeren $C D 4+$ ve $C D 8+T$ lenfositlerin farelere enjeksiyonu ile $A A^{\prime} n ı n$ deneysel olarak immün yetmezlikli farelere greftlenmiş olan insan derisinde indüklenebildiği gösterilmiştir52. Ağırlıklı olarak T hücrelerce kıl follikülünün harabiyete uğratıldığı $A A^{\prime} l ı$ hastaların serumlarında otoantikorlar da saptanmıştır48-51. Antikor yanıtının anagen kıl follikülüne ait çok çeşitli yapılara karşı da gelişebildiği gösterilmiş olsa da bu antikorların patojenisitelerine ait yeterli veriye henüz ulaşılamamıştır51,54. Histopatolojik olarak AA anagen kıl follikülü çevresinde yoğun perifolliküler lenfosit infiltrasyonunun görüldüğü bir tabloya sahiptir. Infiltratta çoğunlukla CD4+ ve CD8+ T hücreler, daha az miktarda ise süpresör T hücreler yer almaktadır. T hücrelerden salınan IFN- $\gamma^{\prime}$ nın anagen kıl follikülü üzerinde destrüktif etki gösterdiği 
bilinmektedir46,55. T hücre subtiplerinin azalmasını sağlayan tedavi yöntemleri ile (örn. topikal ve intralezyonel steroitler) saç çıkımının tekrar elde edilmesi, otoantikorların varlığı, etkilenmiş hayvan modellerinden etkilenmemiş olanlara deneysel ortamda AA transfer edilebilmiş olması ve immunsuprese hayvanlarda greftlenen alanlarda remisyonun indüklenebilmesi gibi hayvan deneyleri bulguları ile de $A A^{\prime} n ı n$ otoimmmün mekanizmalar ile tetiklendiği açıkça desteklenmiştir46-55. Bu otoimmün reaksiyonu başlatan antijen henüz tanımlanamamış olsa da bazı araştırmacılar AA hedef antijenin kıl follikülünde bulunan melanositik bir komponent olabileceğini önermişlerdir46,53.

\section{Kaynaklar}

1. Bangert C, Brunner PM, Stingl G. Immune functions of the skin. Clin Dermatol 2011;29:360-76.

2. Debenedictis C, Joubeh S, Zhang G, Barria M, Ghohestani RF. Immune functions of the skin. Clin Dermatol 2001;19:573-85.

3. Elias PM. Stratum corneum defensive functions: an integrated view. J Invest Dermatol 2005;125:183-200.

4. Gasque P. Complement: a unique innate immune sensor for danger signals. Mol Immunol 2004;41:1089-98.

5. Streilein JW. Skin-associated lymphoid tissues (SALT): origins and functions. J Invest Dermatol. 1983; 80:12-6.

6. Champion RH, Burton L, Burns DA, Breathnach SM. Textbook of dermatology. 6th ed. New York: Blackwell Science, 1998.

7. Shwarz T. Overview of basic science. Immunology. In Bolognia JL, Jorizzo JL, Rapini RP eds. Dermatology. Vol 1. 1st ed,. Spain: Elsevier; 2003;65-81.

8. Abbas AK, Litchman AH, Pober JS. Cellular and molecular immunology. 4th ed. Philadelphia: WB Saunders, 2000.

9. Mackay IR. Science, medicine, and the future of tolerance and autoimmunity. BMJ 2000;321:93-96.

10. Loser K, Beissert S. Therapeutic modulation of cutaneous autoimmunity by regulatory T cells. Rheumatology 2006;45:20-2.

11. Ghoreschi K, Weigert C, Röcken M. Immunopathogenesis and role of T cells in psoriasis. Clin Dermatol 2007;25:574-80.

12. Racke MK, Bonomo A, Scott DE, et al. Cytokine-induced immune deviation as a therapy for inflammatory autoimmune disease. J Exp Med 1994;180:1961-6.

13. Katz JD, Benoist $C$, Mathis $D$. T helper cell subsets in insulindependent diabetes. Science 1995;268:1185-8.

14. Mauri C, Williams RO, Walmsley M, Feldmann M. Relationship between Th1/Th2 cytokine patterns and the arthritogenic response in collagen-induced arthritis. Eur J Immunol 1996;26:1511-8.

15. Powrie F, Leach MW, Mauze S, Menon S, Caddle LB, Coffman RL. Inhibition of Th1 responses prevents inflammatory bowel disease in scid mice reconstituted with CD45RBhi CD4+ T cells. Immunity 1994;1:553-62.

16. Biedermann T, Mailhammer R, Mai A, et al. Reversal of established delayed type hypersensitivity reactions following therapy with IL-4 or antigen-specific Th2 cells. Eur J Immunol 2001;31:1582-91.

17. Austin LM, Ozawa M, Kikuchi T,Walters IB, Krueger JG. The majority of epidermal T cells in psoriasis vulgaris lesions can produce type 1 cytokines, interferon-gamma, interleukin-2, and tumor necrosis factoralpha, defining TC1 (cytotoxic T lymphocyte) and TH1 effector populations: a type 1 differentiation bias is also measured in circulating blood $T$ cells in psoriatic patients. J Invest Dermatol 1999;113:752-9.

18. Komiyama Y, Nakae S, Matsuki T, et al. IL-17 plays an important role in the development of experimental autoimmune encephalomyelitis. I Immunol 2006;177:566-73.

19. Langrish $\mathrm{CL}$, Chen $\mathrm{Y}$, Blumenschein $\mathrm{WM}$, et al. IL-23 drives a pathogenic $T$ cell population that induces autoimmune inflammation. J Exp Med 2005;201:233-40.

20. Nestle FO, Conrad C, Tun-Kyi A, et al. Plasmacytoid predendritic cells initiate psoriasis through interferon-alpha production. J Exp Med 2005;202:135-43.

21. Ghoreschi K, Thomas P, Breit $S$, et al. Interleukin-4 therapy of psoriasis induces Th2 responses and improves human autoimmune disease. Nat Med 2003;9:40-6.
22. Harrington $L E$, Hatton $\mathrm{RD}$, Mangan $\mathrm{PR}$, et al. Interleukin 17-producing CD4+ effector T cells develop via a lineage distinct from the $T$ helper type 1 and 2 lineages. Nat Immun 2005;6:1123-32.

23. Ghoreschi K, Mrowietz U, Röcken M. A molecule solves psoriasis? Systemic therapies for psoriasis inducing interleukin 4 and Th2 responses. J Mol Med 2003;81:471-80.

24. Sakaguchi S, Sakaguchi N, Asano M et al. Immunologic self-tolerance maintained by activated T cells expressing IL-2 receptor alpha-chains (CD25). Breakdown of a single mechanism of selftolerance causes various autoimmune diseases. J Immunol 1995;155:1151-64.

25. Herold KC, Hagopian W, Auger JA et al. Anti-CD3 monoclonal antibody in new-onset type 1 diabetes mellitus. N Engl J Med 2002;346:1692-8.

26. Sugiyama $H$, Gyulai $R$, Toichi $E$ et al. Dysfunctional blood and target tissue CD4 + CD25 high regulatory T cells in psoriasis: mechanism underlying unrestrained pathogenic effector T cell proliferation. J Immunol 2005;174:16473.

27. Ruocco V, Ruocco E, Lo Schiavo A et al. Pemphigus: Etiology, pathogenesis, and inducing or triggering factors: Facts and controversies. Clin Dermatol 2013;31:374-81.

28. Veldman C, Höhne A, Dieckmann D et al. Type I regulatory T cells specific for desmoglein 3 are more frequently detected in healthy individuals than in patients with pemphigus vulgaris. J Immunol 2004;172:6468-75.

29. Najafian N, Khoury SJ, Sayegh MH. T cell costimulatory blockade as a novel immune intervention in autoimmune diseases. Clin Dermatol 2001;19:58691.

30. Schwartz RH. A cell culture model for T lymphocyte clonal anergy. Science 1990;248:1349-56

31. Reiser $\mathrm{H}$, Stadecker MJ. Costimulatory B7 molecules in the pathogenesis of infectious and autoimmune diseases. N Engl J Med 1996;335:1369-77.

32. Sayegh MH, Turka LA. The role of T-cell costimulatory activation pathways in transplant rejection. N Engl J Med 1998;338:1813-21.

33. Finck BK, Linsley PS, Wofsy D. Treatment of murine lupus with CTLA4Ig. Science 1994;265:1225-7.

34. Tang A, Judge TA, Turka LA. Blockade of CD40-CD40 ligand pathway induces tolerance in murine contact hypersensitivity. Eur J Immunol 1997;27:3143-50.

35. Hertl M, Riechers R. Autoreactive T cells as potential targets for immunotherapy of autoimmune bullous skin diseases. Clin Dermatol 2001;19:5927.

36. Anhalt GJ, Labib RS, Voorhees JJ et al. Induction of pemphigus in neonatal mice by passive transfer of IgG from patients with disease. N Engl J Med 1982;306:1189-96.

37. Merlob P, Metzker A, Hazaz B et al. Neonatal pemphigus vulgaris. Pediatrics 1986;78:1102-5.

38. Bystryn JC, Steinman NM. The adjuvant therapy of pemphigus. An update. Arch Dermatol 1996;132:203-12.

39. Rock B, Labib RS, Diaz LA. Monovalent Fab immunoglobuline fragments from endemic pemphigus foliaceus autoantibodies reproduce the human disease in neonatal Balb/c mice. J Clin Invest 1990;85:296-9.

40. Grando SA, Bystryn JC, Chernyavsky Al, et al. Apoptolysis: a novel mechanism of skin blistering in pemphigus vulgaris linking apoptotic pathways to basal cell shrinkage and suprabasal acantholysis. Exp Dermatol 2009;18:764-70.

41. Ortonne J. Vitiligo and other disorders of Hypopigmentation. In: Bolognia J, Jorizzo J, Rapini R, eds. Dermatology. Vol 1. 2nd. Spain: Elsevier; 2008:91320.

42. Le Poole IC, Luiten RM. Autoimmune etiology of generalized vitiligo. Curr Dir Autoimmun 2008;10:227-43.

43. Ongenae K, Van Geel N, Naeyaert JM. Evidence for an autoimmune pathogenesis of vitiligo. Pigment Cell Res. Apr 2003;16:90-100.

44. Zhang BX, Lin M, Qi XY, Zhang RX, et al. Characterization of circulating CD8+T cells expressing skin homing and cytotoxic molecules in active non-segmental vitiligo. Eur J Dermatol. Jun 192013.

45. Van den Wijngaard RM, Aten J, Scheepmaker A, et al. Expression and modulation of apoptosis regulatory molecules in human melanocytes: significance in vitiligo. Br J Dermatol 2000;143:573-81.

46. Sperling LC. Alopecias. In: Bolognia J, Jorizzo J, Rapini R, eds. Dermatology. Vol 1. 2nd. Spain: Elsevier; 2008: 992-5. 
47. Huang KP, Mullangi S, Guo Y, et al. Autoimmune, Atopic, and Mental Health Comorbid Conditions Associated With Alopecia Areata in the United States. JAMA Dermatol 2013;149:789-94

48. Puavilai S, Puavilai G, Charuwichitratana S, Sakuntabhai A, SriprachyaAnunt S. Prevalence of thyroid diseases in patients with alopecia areata. Int J Dermatol 1994;33:632-3.

49. Werth VP, White WL, Sanchez MR, et al. Incidence of alopecia areata in lupus erythematosus. Arch Dermatol 1992;128:368-71.

50. Wang SJ, Shohat T, Vadheim C, Shellow W, Edwards J, Rotter JI. Increased risk for type I (insulin-dependent) diabetes in relatives of patients with alopecia areata (AA). Am J Med Genet 1994;51:234-9.

51. McElwee KJ, Tobin DJ, Bystryn JC, et al. Alopecia areata: an autoimmune disease? Exp Dermatol 1999;8:371-9.
52. Gilhar A, Landau M, Assy B, et al. Mediation of alopecia areata by cooperation between CD4+ and CD8+ T lymphocytes: transfer to human scalp explants on Prkdc(scid) mice. Arch Dermatol 2002;138:916-22.

53. Gilhar A, Landau M, Assy B, et al. Melanocyte-associated T cell epitopes can function as autoantigens for transfer of alopecia areata to human scalp explants on Prkdc(scid) mice. J Invest Dermatol 2001;117:1357-62.

54. Hedstrand H, Perheentupa J, Ekwall O, et al. Antibodies against hair follicles are associated with alopecia totalis in autoimmune polyendocrine syndrome type I. J Invest Dermatol 1999;113:1054-8.

55. Gilhar $A$, Kam Y, Assy B, et al. Alopecia areata induced in $\mathrm{C} 3 \mathrm{H} / \mathrm{HeJ}$ mice by interferon-gamma: evidence for loss of immune privilege. J Invest Dermatol 2005:124:288-9. 